\title{
The aging process and health: what middle-aged people think of the issue
}

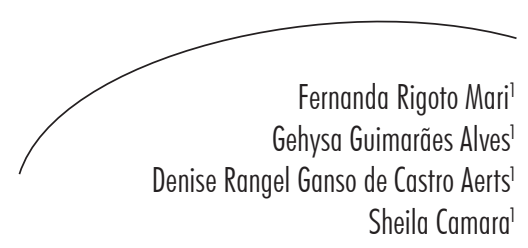

\section{Abstract}

Objective: To understand the perception of middle-aged adults regarding health and the aging process. Method: A qualitative study involving 30 adults aged 45 to 59 years old, 15 of whom were female and 15 of whom were male, who answered open questions about their perception of health and aging. Data was analyzed using the thematic content analysis technique. Results: Almost half of the respondents had not finished elementary school and only three had a university degree. A total of 27 were married, five were retired and 25 worked in the service provider sector, 26 were Caucasian, and 27 belonged to social-economic class B. The perception of health was described as being related to taking care of oneself (physical, mental and spiritual welfare), to being active and having the will to live. Regarding aging, the middle-aged persons had already begun to perceive signs of this process such as slowness to perform daily tasks, fatigue, muscle Key words: Health; Aging; Middle Aged. pain, rheumatic pain, a slowing of weight loss, gray hair, impaired vision and hearing, difficulty performing some movements, marks on skin and forgetfulness. Regarding protective actions, the practicing of physical activity, a healthy diet, social and family life and having some sort of occupation were mentioned. The greatest desire was to reach an older age with good health, independence and good living conditions. Conclusion: Although the data of the present study cannot be generalized, it is an important starting point for future research, since the results reveal concerns that can be reduced to support programs of healthy aging.

\footnotetext{
Universidade Luterana do Brasil, Programa de Pós-graduação em Saúde Coletiva. Canoas, RS, Brasil.
}

Correspondence

Fernanda Rigoto Mari

E-mail: ferigoto@gmail.com 


\section{INTRODUCTION}

The repercussions of the aging process on our society are considerable, particularly in the health sector. With increasing longevity, people now want to live longer with better health and a better quality of life. This demonstrates the importance of developing public policies that promote independence and a healthy lifestlye. ${ }^{1,2}$

Most countries worldwide are now dealing with an aging population. The aging process does not begin during adulthood. It is a life-long process, although the characteristics of the process only become evident when a person reaches approximately 60 years of age. 3,4

Studies of perceptions of aging are important in the planning of public policies, given that people's behavior has been correlated with these perceptions and the value they are given. ${ }^{5}$

People's perceptions about their health have a signigficant impact on health and the aging process, while also representing a lifestyle predictor. Selfperception is multi-dimensional and is affected by the capacity of an individual to respond to the demands of daily life. ${ }^{6}$

Self-perceptions about health are understood to be an individual's interpretation of acquired knowledge and life experiences. This is an important index when assessing an individual's health status, since it deals with physical and emotional dimensions and affects their functional capacity. It can also be a mortality predictor. ${ }^{6}$

An assessment of an individual's health perceptions involves both subjective and objective aspects, with the former related to how the individual feels and judges their own life..$^{8,9} \mathrm{~A}$ negative perception of one's own health can be caused by pain, discomfort or malaise and has been correlated with social, cultural, psychological and environmental factors. Previous studies ${ }^{10,11}$ of health perceptions have indicated that women, the elderly, uneducated people and black people are more likely to refer to their health in a negative manner. Due to the importance of research into self-perceptions, the aim of the present study was to determine the perceptions of middle-aged adults on the aging process and health.

\section{METHODS}

This qualitative, descriptive study involved 30 people (15 male and 15 female) aged between 45 and 59 years. The participants were initially selected by a researcher in restaurants, schools and a gym. Thus, the sample was classified as nonprobabilistic. The interviewees were selected based on the indications of people who knew somebody in the relevant age group that fulfilled the inclusion criteria (aged between 45 and 59 years and living in the municipality of Caxias do Sul, Rio Grande do Sul, Brazil).

Caxias do Sul is located in the state of Rio Grande do Sul (RS) in the south of Brazil. It has a total area of $1,643,913 \mathrm{~km}^{2}$ and a population of approximately 716,421 . The population of middleaged residents in the municipality is $80,674(38,403$ men and 42,271 women). In the state of RS, there are 982,739 men and 1,067,672 women, while in Brazil, these totals are 14,429,352 (men) and $15,820,620$ (women). ${ }^{12}$

The first contact with the interviewees was made by telephone. If the individual agreed to do the interview, a date and location was scheduled. Data was collected between May and June of 2013.

A self-administered instrument containing the variables age, gender, skin color (self-perception), education and economic classification was used. The latter was classified as A, B, C, D or E, based on the Associação Brasileira de Empresas de Pesquisa (Brazilian Association of Research Companies) (ABEP) classification. ${ }^{13}$ The qualitative data was collected using the following open questions: "What does health mean to you?"; "What does a person's health depend on?"; "What do you do to stay healthy?"; "How do you feel about getting old?; Have you noticed signs of aging in your life?"; "What have you done to combat this?"; and "Have 
you noticed any difficulty in performing your activities due to health reasons?".

The analysis of thematic content method proposed by Minayo ${ }^{14}$ was used to analyze the qualitative data. Since the responses to these questions were very similar, they were divided into three goups: health perceptions; the aging process; and self-protection actions. The interviewees were given fictitious names in the presentation of the data.

This project was approved by the Research Ethics Committee of the Universidade Luterana do Brasil under registration number CAAE: 14434813.8.0000.5349. All of the participants signed a Free and Informed Consent Form (FICF).

\section{RESULTS AND DISCUSSION}

\section{Characterization of the interviewees}

The study sample was composed of 30 adults (15 men and 15 women), aged between 45 and 59 years. Almost half of the interviewees (12) had not completed primary education, whereas three had completed higher level education. Almost all of the participants were married (27), considered themselves white (26) and were classified as socioeconomic class B (27), according to the ABEP economic classification. ${ }^{13}$ Concerning their careers, five were retired, although of these five, three had begun working again by the time of the interview. The professions of those who worked were varied, although most of them were somehow connected to the provision of services.

\section{Health perceptions}

When asked about how they conceptualized health, the interviewees linked health to eating well (21); physical exercise (13); having some type of occupation (10); physical, mental and spiritual wellbeing (9); taking care of oneself (7); family and social life (5); medical care (5); personal hygiene (1); and keeping mentally active (1). Living life to the fullest was also mentioned, as well as the importance of sleeping well (5), leisure time (4) and maintaining contact with nature (2). For the vast majority of the interviewees, health was considered the most important factor for a high quality of life.

When discussing nourishment, Maria explained that "[...] you need to eat healthy things, with less pesticides". She also stated that it is important to drink less soft drinks and more natural fruit juice. Ana stated that if a person eats carefully, they don't need to go to the doctor so much. Rosa said that health is associated with "[...] the things that make up our routine, being careful about what you eat and doing some exercise". Exercise was classified as fundamental by many of the interviewees.

Changing one's habits and customs requires patience and care, particularly when these habits are linked to a person's lifestyle. Nutrition and nourishment are factors that affect the quality of life of an individual and provide them with greater longevity. ${ }^{15,16}$ Physical exercise helps adults to perform better in their jobs and protects them from chronic diseases such as diabetes, obesity, high blood pressure and osteoporosis. Among the middle-aged and elderly, exercise has been strongly correlated with wellbeing, since the body and mind need activity in order to avoid stagnation in these phases of life. ${ }^{17,18}$ Regular physical activity maintains the function of the muscles, bones and joints. It also maintains blood and hormonal levels within the adequate parameters and stimulates intestinal and immunological equilibrium. People that exercise throughout their lives usually sleep better and are more disposed to perform their daily activities. They are also less likely to suffer from diseases due to a healthier aging process, with better balance, mobility, flexibility and self-esteem. ${ }^{19,20}$

Feeling good about oneself is one of the reasons why middle-aged people try to maintain some form of physical activity, which provides them with obvious health benefits and results in an improvement in body satisfaction. ${ }^{21,22}$ Cultural factors affect people's understanding of the aging process and the development of lifestyles. ${ }^{23}$ They also influence how society views the elderly population and the aging process. ${ }^{24}$ 
According to the World Health Organization (WHO), quality of life is defined by people's perceptions of their own lives in terms of culture and the values associated with their goals, standards and worries. This concept has been correlated with environmental, physical and psychological factors, as well as the individual's level of independence, their social relationships and personal beliefs. ${ }^{25}$ Quality of life can be promoted through public health policies.

Concerning medical care, five of the interviewees mentioned the importance of preventive action and continuous self-assessments of their health. João spoke of the need to "[...] look after yourself. We are getting older, so we need to go to the doctor. I have a checkup once a year. If you want good health, you need good medical care". For this participant, it was also importtant to take care of "[...] what we eat and drink". Olívia stated that she was trying to stop using controlled medications for depression and rheumatism. She has tried to replace them with walks, which she never did before. Ana said that in order to have a healthy body, you need a healthy mind, thereby highlighting the significance of the relationship between the mind and body. Physical and emotional wellbeing were considered important health factors. According to José, a healthy mind, with positive thoughts, helps a person to obtain a better quality of life.

Having some sort of occupation (10), whether paid or not, was also deemed necessary for emotional health, given that it improves the individual's disposition. Marta stated that walking, working and keeping the mind and body busy are necessary if you want to stay healthy.

The results of the present study are in agreement with those reported in a qualitative study ${ }^{26}$ of 4060 adults and 4003 elderly residents in regions containing 240 basic health units in the south and north-east of Brazil (2005). According to the adults assessed, the most important factors for health were healthy nourishment (33.8\%), physical exercise (21.4\%) and a healthy lifestyle, in particular, not smoking (13.9\%). According to the elderly individuals, the most important factors were healthy nourishment (36.7\%), not smoking (17.7\%) and regular visits to a doctor (14.2\%). This study ${ }^{26}$ confirmed that most adults and elderly individuals recognize and recommend careful eating as an essential component of a healthy lifestlye.

In the present study, $56.6 \%$ of the middle-aged adults also mentioned careful eating, whereas $46.6 \%$ cited physical exercise and $6.6 \%$ mentioned not smoking. All of these factors were considered significant to an individual's health.

\section{Self-protection for healthy living}

When questioned about what they did to stay healthy, only two of the interviewees claimed to do nothing. Margarete had been advised to perform physical exercise to minimize rheumatic pain, although she said it was very difficult to stay active. Bolivar claimed to be aware of the importance of physical exercise, but was not able to find the time to do any. Olívia stated that she did not worry about aging, preferring not to think about it and to concentrate on her work: "[...] so the years pass and you barely notice that you are getting older". It is notable from these comments that, despite the fact that the respondents recognized that physical exercise is a health protector, this knowledge alone was not enough. It must be put into action, which often requires discipline and courage. ${ }^{27}$

Encouraging people to adopt a healthy lifestyle is not always easy, since it involves changing the way they live their lives. ${ }^{28}$ Promoting a healthy lifestyle is essential as it teaches these people that they can make healthy life choices and do what is required to attain a better quality of life. Thus, it is important that each individual identifies their needs and takes responsibility for their own care. ${ }^{29,30}$

With the increasing prevalence of nontransmittable chronic diseases that are linked to lifestyle choices and a lack of physical exercise, the Brazilian government has created a number of projects that promote healthy norishment, a healthy lifestyle and physical exercise. ${ }^{31,32}$ Concerning healthy aging, the $\mathrm{WHO}$ has recommended the 
expansion of access to health services and social services, with a focus on health promotion, the adoption of healthy habits (nourishment and exercise), the avoidance of tobacco and alcohol, and care when self-medicating. It is also necessary to provide a physical environment that prevents accidents and the abuse of elderly individuals, while appreciating their work in informal business, the home and the communities in which they live. ${ }^{33}$ In order to ensure these determinants, it is important to involve several sectors of society, including those responsible for quality transport, jobs, social justice, housing and safety, among others. ${ }^{34}$ Therefore, there is a need for inter-sector actions, in which health promotion is used as a strategy to overcome the health problems of the population. These projects should involve technical knowhow, traditional knowledge and the mobilization of both public and private resources. ${ }^{35,36}$

Among the interviewees who actively tried to stay healthy, the vast majority performed physical exercise (gym, swimming and walking) and ate carefully, avoiding overeating, fried foods, sugars and white flour. Serafina stated that as her work routine is quite rigorous and consequently, she has no time to go to a gym. In order to supplement her lack of regular physical exercise, she walks up and down the stairs at home for a period of time. She explained that "[...] it makes me feel better, since I need strong legs in my job". This comment demonstrated her perception of the importance of keeping active for her health and quality of life.

The interviewees mentioned several strategies that could improve their health and quality of life. Antônio said he tried to go to bed early and get up early, believing that this provided him with more vitality. Marcos said that he did not perform physical exercise but he did go to bed early and walk to work. João said that he eats carefully and goes to the doctor regularly to control his health. He also rarely consumes alcohol and when he does, the quantities are small. Carlos claimed to eat carefully, work and try to live life to the fullest, by going out with friends to restaurants and the cinema. He believes that being healthy means feeling good and these activities help increase his wellbeing.

These results are similar to those reported in an earlier study ${ }^{37}$ containing 67 people, divided into young adults, middle-aged adults and elderly individuals. The interviewees were found to exhibit the following determinants of illness: a poor diet; alcohol and drug consuption; a lack of concern about their general health; a lack of exercise; not sleeping enough; exposure to the sun or cold temperatures; working too much and social isolation. Another study ${ }^{38}$ of middle-aged individuals confirmed that there needs to be some sort of threat to their health for them to adhere to physical exercise programs as a regular part of life. Nevertheless, the interviewees were aware of the benefits these programs would provide. Other studies ${ }^{39-41}$ have stated that if a person starts to do physical exercise and eat a healthy diet at an earlier age, they will have a greater chance of aging healthily, given that the activities of a healthy lifestyle are already incoprorated into their life. These results confirm the importance of staying active and being able to enjoy the health benefits that this activity provides.

\section{Perceptions about the aging process}

The importance of healthy aging was highlighted by six of the interviewees in the present study. The reason this number was so low may have been because the majority of the participants had not yet noticed signs of aging in their lives. However, for people such as Lídia, "[...] if you are going to get old, it has to be with your health. It is good to get old like that. As the years go by, we gain experience". Rita stated that she was very much afraid of aging, getting sick, requiring care and being unable to continue living alone: "[...] I am afraid of being a burden to others". Maria added that "[...] the old become a worry for everybody, dont they? Everybody wants to grow old, but nobody wants to die [...], everybody wants to be able to walk and remain lucid in their old age. If not, they become a burden for their family". 
A number of the interviewees said that it was terrible to grow old and realize that you didn't do things that you should have done. They said that it is not good to regret the things that you never did. Sometimes, they worked too hard and became stressed, which affected their sleeping and eating habits. This also affected their health and quality of life.

An earlier study ${ }^{42}$ of adults and elderly individuals confirmed that the aging process was noticed by almost all of the interviewees over the course of their lives, which is similar to the results of the present study. The elderly individuals claimed to notice greater physical limitations, whereas adults were more concerned with esthetics and their social lives, although they still confirmed a fear of growing old. The middleaged participants in the present study preferred the strategy of simply not thinking about aging. Some of them worried about esthetic issues, such as spots on their skin and grey hair. Work was considered a great way of staying in touch with other people. However, it is essential that people confront the reality of the aging process so that they can take the required action to achieve healthy aging. Longevity is a common concern in society and is often associated with physical capacity. Improvements in living conditions can increase the elderly population. Although these people want to live longer, they are often in denial about the aging process. ${ }^{43}$

Since the aging process occurs throughout our lives, its signs are self-perceivable, depending on the age of the individual, and become more obvious with increasing age. ${ }^{44}$ Aging is dependent on factors such as a person's history and their individual understanding of this process. Often, culture and self-perceptions affect how aging is perceived. Understanding and accepting this process is of great importance if an individual is to experience healthy and independent aging. ${ }^{45}$

Concerning this denial of aging, Adão (age: 57 years) claimed not to have noticed any changes in his life and did not feel that he was aging. He had worked up until the age of 55 and was currently very active, "[...] like a young boy, I go dancing all night, I go to the gym and I run for 45 minutes". Olívia also claimed not to have noticed any signs of aging and said that she lived her life normally.

However, perceptions about aging are exhibited in different ways. Some people see this period as empty and meaningless, without an occupation or value. Forgetfulness, loss of muscle mass, increased vulnerability and the increased probability of death appear throughout our lives, particularly after 40 or 50 years of age, and were all mentioned by the interviewees. As a result, it is important that people are able to look at themselves and notice the changes that are happening, in order to adapt to this new phase of life. ${ }^{46,47}$

Being aware of the passing of time is essential to our wellbeing. When we begin to perceive the aging process, issues such as death and finiteness arise more frequently. It is important that, instead of denying the aging process, people understand what is taking place and its inevitability. ${ }^{48-50}$ Most people do not like to talk or think about the fact that it will all (good and bad) end one day. If a person becomes upset at the thought of the finite nature of life, they are more likely to develop emotional illnesses and consequently, are less lilely to age healthily. Annoyance at the finite nature of life does not decrease an individual's strength or relieve their pain. On the contrary, it amplifies their pain and turns it into suffering. Accepting that everything has a beginning, a middle and an end allows people to enjoy their lives and live them to the fullest. ${ }^{51}$

The vast majority of people hope to grow old with health, independence and satisfactory living conditions (housing, nourishment, education and work), among others. ${ }^{52}$ Historical, social, genetic and environmental factors can have positive or negative effects on how we age, as can the manner in which we deal with stress and our level of expoisure to certain pathologies. ${ }^{53,54} \mathrm{~A}$ previous study ${ }^{55}$ of individuals aged between 18 and 65 years confirmed that the causes of disease among 
middle-aged people are correlated with a poor diet and inadequate personal care. Despite noticing signs of aging, such as slowness during daily tasks, tiredness, muscle pains, rheumatism, difficulty in losing wight, grey hair, worsening vision and hearing, movement issues, spots on their skin and forgetfulness, many of the participants were not able to adapt and live a healthier lifestyle.

Mario stated that his work was starting to wear him out and he felt that people tended to get slower. According to Marta, it is important to keep the mind occupied to avoid depression. Hibiscos noticed that his sight had worsened over time and he believed that it was because he had worked with a computer for a long time. Lídia highlighted pains in her arms and legs that hindered the performance of certain tasks, which she had previously done automatically.

Aging occurs differently for everybody and is affected by an individual's lifestyle and genetic factors. Factors such as a decrease in fuctional capacity and suscepticibility to chronic diseases (acquired with age) can be reduced by adopting a healthier lifestyle. It is important that people pay more attention to themselves if they are to notice the signs of aging. ${ }^{56}$

Many of the interviewees in the present study said that they did not want to think about getting old. This avoidance can be transformed into suffering and leave people unprepared for the limitations that are inherent to this stage of life. They need to develop a positive view of their life so that they can work in accordance with their psychological well-being and consequently, their health. ${ }^{56}$

The results of the present study could help the planning of actions that will positively affect perceptions about the aging process. Most of the interviewees had not completed primary education, which could be seen as a limitation of this study. People with a more complete education did not agree to participate. Another limitation is the fact that, since this is a qualitative study, it is not possible to generalize the results. Therefore, further studies are suggested, with a qualitative approach and a larger sample, in order to extapolate the data for the general population and guide the planning of public policies. On a positive note, the participants were genuinely interested in talking about this issue and reflecting on the questions asked during the interview.

\section{CONCLUSION}

Most of the interviewees recognized that physcial activity and a healthy diet are associated with physical and emotional wellbeing and can lead to a better quality of life. Although every person ages differently, the manner in which they perceive these changes in their body determines how much care they will dedicate to this process. Many of the participants preferred not to think about this subject, despite the fact that they could feel these changes occuring in their lives. Denial leads to illness, given that a person can only improve their physical and emotional health by paying attention to these aspects of life. To do so, people must choose to reflect on old age and prepare for this stage of life, thereby achieving their goals and living a fuller life.

Understanding how middle-aged people perceive their own health, as well as how they feel about the aging process and what they do to stay healthy, could help the planning of public policies that promote a healthy lifestyle among middle-aged and elderly populations. Active aging programs that encourage people to live a healthy lifestyle and take responsibility for their own selfcare could contribute to a better quality of life in these populations. Based on the results of the present study, these programs are important as many people are not capable of modifying their lifestyle, despite knowing how important it is to do so. If public policies stimulated and facilitated healthy practices, it is possible that more people would adhere to these activities. This is a challenge that faces all those who deal with middle-aged and elderly populations. 


\section{REFERENCES}

1. Vilarta R, organizador. Alimentação saudável e atividade física para a qualidade de vida. Campinas: IPES Editorial; 2007.

2. Carvalho JAM, Garcia RA. O envelhecimento da população brasileira: um enfoque demográfico. Cad Saúde Pública 2003;19(3):725-33.

3. Camarano AA, Kanso S. Perspectivas de crescimento para a população brasileira: velhos e novos resultados. Rio de Janeiro: Ipea; 2009. (Texto para Discussão, n. 1.426).

4. Teixeira AC, Barbosa RSP. Avaliações psicossociais de adultas na meia idade. Bol Inf Unimotrisaude Sociogerontol 2011;2(1):56-73.

5. Borim FSA, Barros MBA, Neri AL. Autoavaliação da saúde em idosos: pesquisa de base populacional no Município de Campinas, São Paulo, Brasil. Cad Saúde Pública 2012;28(4):769-80.

6. Lima CMF, Peixoto SV, Matos DL, Firmo JOA, Uchôa E. A influência de respondente substituto na percepção da saúde de idosos: um estudo baseado na Pesquisa Nacional por Amostra de Domicílios (1998, 2003) e na coorte de Bambuí, Minas Gerais, Brasil. Cad Saúde Pública 2007;23(8):1893-902.

7. Portillo JC, Paz AM. Autopercepção de qualidade de vida relativa à saúde bucal. Rev Bras Odontol Saúde Coletiva 2000;1(1):75-88.

8. Bezerra PCL, Opitz SP, Koifman RJ, Muniz PT. Percepção de saúde e fatores associados em adultos: inquérito populacional em Rio Branco, Acre, Brasil, 2007-2008. Cad Saúde Pública 2011;27(12):2441-51.

9. Neri AL. Idosos no Brasil: vivências, desafios e expectativas na terceira idade. São Paulo: Fundação Perceu Abramo: Edições Sesc; 2007.

10. Franks P, Gold MR, Fiscella K. Sociodemographics, self-rated health, and mortality in the US. Soc Sci Med 2003;56(12):2505-14.

11. Vuorisalmi M, Lintonen T, Jylha M. Global self- rated health data from a longitudinal study predicted mortality better than comparative self-rated health in old age. J Clin Epidemiol 2005;58(7):680-7

12. Instituto Brasileiro de Geografia e Estatística [Internet]. Rio de Janeiro: IBGE; 1995-. Cidades@: Rio Grande do Sul; 2014 [acesso em 12 jun.
2014]; [aproximadamente 2 telas]. Disponível em: bhttp://www. cidades.ibge.gov.br/xtras/perfil. php?lang $=\&$ codmun $=430510 \&$ search=rio-grandedo-sul $\% 7$ Ccaxias-do-sul

13. Associação Brasileira de Empresas de Pesquisa. Critério de classificação econômica Brasil 2010 [internet]. São Paulo: ABEP; 2012 [acesso em 20 jul 2013]. Disponível em: http://www.abep.org/ codigoguias/ABEP_CCEB.pdf

14. Minayo CS. O desafio do conhecimento: pesquisa qualitativa em saúde. 10 ed. São Paulo: Hucitec; 2007.

15. Tyrovolas S, Panagiotakos D. The role of Mediterranean type of diet on the development of cancer and cardiovascular disease, in the elderly: a systematic review. Maturitas 2010;65(2):122-30.

16. Fernandes BLV. Atividade física no processo de envelhecimento. Rev Portal Divulg 2014;4(40):46-8.

17. Allsen PE, Harrison JH, Vance B. Exercício e qualidade de vida: uma abordagem personalizada. São Paulo: Manole; 2001.

18. Nahas MV. Atividade física, saúde e qualidade de vida: conceitos e sugestões para um estilo de vida ativo. 2 ed. Londrina: Midiograf; 2001.

19. Rodrigues DS. Atividade física na prevenção e no controle dos fatores de risco para as doenças cardiovasculares [trabalho de conclusão de curso]. Campina Grande, PB: Universidade Estadual da Paraíba, Faculdade de Farmácia; 2014.

20. Cipriani NCS, Meurer ST, Benedetti TRB, Lopes MA. Aptidão física funcional de idosas praticantes de atividades físicas. Rev Bras Cineantropom Desempenho Hum 2010;12(2):106-11.

21. Souto S, Ferro-Bucher JSN. Práticas indiscriminadas de dietas de ema grecimento e o desenvolvimento de transtornos alimentares. Rev Nutr 2006;19(6):693-704.

22. Reis AES, Souza JA. Atividade física para idosos. Rev Iniciaç Cient Univ Vale do Rio Verde 2011;1(2):1-1.

23. Lindolfo MC, Sá SPC, Leite AP, Maciel CO, Silva INT. Atendimento domiciliário ao idoso dependente de cuidados de enfermagem: realidade dificuldades. Enferm Atual 2007;39(7):25-32.

24. Organização Pan-Americana da Saúde. Envelhecimento ativo: uma política de saúde. Brasília, DF: Ministério da Saúde; 2005. 
25. World Health Organization. The world Health Organization Quality of Life Assessment (WHOQOL): position paper from the World Health Organization Soc Sci Med 1995;41(10):1403-9.

26. Siqueira FV, Nahas MV, Facchini LA, Silva DS, Piccini RX, Tomasi E, et al. Fatores considerados pela população como mais importantes para manutenção da saúde. Rev Saúde Pública 2009;43(6):961-71.

27. Ganzo C, Aerts D. A Arte de se fazer feliz: libreto 2. Porto Alegre: Bororo 25; 2013.

28. Sakraida TJ, Nola P. Health promotion model. In: Tomey AM, Alligood MR. Nursing theorists and their work. 6th ed. St Louis-Missouri: MosbyElsevier; 2006. p. 452-72.

29. Brasil. Ministério da Saúde. Secretaria de políticas de saúde, projeto promoção da saúde. As cartas da promoção da saúde. Brasília, DF: Ministério da Saúde; 2002.

30. Dos Santos I, Dos Santos AAC, Silva AFL, Caldas CP, Berardinelli LMM, Santana RF. O grupo pesquisador construindo ações de autocuidado para o envelhecimento saudável: pesquisa sociopoética. Esc Anna Nery Rev Enferm 2011;15(4):745-53.

31. Brasil. Ministério da Saúde, Conselho Nacional de Secretários de Saúde. Legislação do SUS. Brasília; Ministério da Saúde; 2003.

32. Matsudo SM, Matsudo VR, Andrade DR, Pratt M, Araújo L. Physical activity promotion: experiences and evaluation of the agita São Paulo program using the ecological mobile model. J Phys Act Health 2004;1:81-97.

33. World Health Organization. WHO Global Strategy on Diet, Physical Activity and Health: the Americas Regional Consultation Meeting Report. Geneva: WHO; 2003.

34. Vitória, ES. Secretaria de Estado da Saúde. Diretrizes Clínicas. Saúde da Pessoa Idosa. Vitória: Secretaria de Estado da Saúde; 2008.

35. Buss PM. Promoção de Saúde e qualidade de vida. Ciênc Saúde Coletiva 2000;5(1):163-77.

36. Westphal MF. Promoção da saúde e prevenção de doenças. In: Campos GWS, Bonfim JBA, Minayo MCS, Akerman M, Drumond M Júnior, De Carvalho YM, organizadores. Tratado de Saúde Coletiva. Rio de Janeiro: Fiocruz, 2006. p.635-667. (Saúde em Debate, vol. 170).
37. Reis JC, Fradique FS. Significações sobre causas e prevenção das doenças em jovens adultos, adultos de meia-idade e idosos. Psicol Teor Pesqui 2003;19(1):224-42.

38. Santos SC, Knijnik JD. "Motivos de adesão à prática de atividade física na vida adulta intermediária adulta intermediária." Rev Mackenzie Educ Fís Esp 2006;5(1):23-34.

39. Duarte VB, Santana MG, Soares MC, Dias DG, Thofern MB. A perspectiva do envelhecer para o ser idoso e sua família. Fam Saúde Desenvolv 2005;7(1):42-50.

40. Gomes KV, Zazá DC. Motivos de adesão a prática de atividade física em idosas. Rev Bras Ativ Fís Saúde 2012;14(2):132-8.

41. Kilpatrick M, Edward H, John B. College students motivation for physical activity: differentiating men's and women's motives for sport participation and exercise. J Am Col Health 2005;54(2):87-94.

42. Romano F. Sentido de corpo e percepção de envelhecimento de adultos e idosos. Rev Bras Ciênc Saúde 2011;8(25):1-10.

43. Marques DT, Pachane GG. Formação de educadores: uma perspectiva de educação de idosos em programas de EJA. Educ Pesqui 2010;36(2):475-40.

44. Ward R. Change in perceived age in middle and later life. Aging Human dev 2013;76(3):251-67.

45. Ramos CR. Comparação da aptidão física em mulheres de meia-idade e idosas com diferentes níveis de atividade física [dissertação]. Vila Real: UTAD; 2011.

46. Kaufmann IG. Perdas, perdas, perdas... Consequências do envelhecimento! Relato de um processo psicoterapêutico com início em atendimento em grupo. In: Divers-idade: subjetividade, cultura e poder. $3^{\circ}$ Congresso Ibero-Americano de Psicogerontologia; 3-5 de nov. 2009; São Paulo. São Paulo: PUCSP; 2009.

47. Fechine BRA, Trompieri N. Processo de envelhecimento: as principais alterações que acontecem com o idoso com o passar dos anos. Rev Cient Int 2012;1(7):106-94.

48. Antunes PC, Silva AM, Baptista TJR. Corpo e saúde na produção acadêmica da educação física brasileira: um estudo centrado na meia idade. Motrivivência 2013;(41):176-89. 
49. Tavares AMC. Adultos maduros e idosos na escola: depoimentos de educadores [Trabalho de conclusão de curso]. Porto Alegre:Universidade Federal do Rio Grande do Sul, Faculdade de Pedagogia; 2013.

50. Rego S, Palácios M. A finitude humana e a saúde pública. Cad Saúde Pública 2006;22(8),755-60.

51. Aerts D; Ganzo C. A felicidade possível. Porto Alegre: Bororó 25; 2011.

52. Somchinda A, Fernandes FC. Saúde e qualidade de vida na terceira idade: uma introspecção dos idosos institucionalizados [especialização]. Brasília DF: Associação Brasileira de Odontologia; 2003.
53. Silva AL, Gonçalves LHT. Cuidado à pessoa idosa: estudos no contexto luso-brasileiro. Porto Alegre: Sulina; 2010.

54. Camarano AA, editor. Cuidados de longa duração para a população idosa: um novo risco social a ser assumido? Rio de Janeiro: IPEA; 2010.

55. Reis J, Fradique F. Desenvolvimento sociocognitivo de significações leigas em adultos: causas e prevenção das doenças. Análise Psicológica; Lisboa 2002;1(20): 5-26.

56. Shills ME et al. Nutrição moderna na saúde e na doença. $10^{\circ}$ ed. São Paulo: Manoele; 2009.

Received: June 26, 2014

Revised: February 2, 2015

Accepted: August 26, 2015 